\title{
THE EFFECTIVENESS OF PICTURE SEQUENCETOWARDSSTUDENTS' ABILITY IN USING CONJUNCTION AT THE EIGHT GRADE OF MTs NEGERI MODEL KOTA SORONG IN THE ACADEMIC YEAR 2016/2017
}

\author{
Ari Wibowo \\ ariwibowo@unimudasorong.ac.id \\ Nursalim \\ nursalim@unimudasorong.ac.id \\ Yuli Astuti \\ astutiyuli@gmail.com
}

\section{Education University of Muhammadiyah Sorong, Indonesia}

\begin{abstract}
Learning writing is one of fourth skill of learning second language that must be mastered by students. For this reason the writers want to investigate and conduct the study in this field. The Statement of Problem 'Is Picture Sequence effective towards students' ability in using conjunctionat the eight grade of MTs. Negeri Model Kota Sorong in the academic year 2016/2017?" the research design in this investigation is experimental research. The population of this study is students in MTs. Negeri Model Kota Sorong and has taken as sample were class VIII-G as a control group and VIII-D as the experimental group. In this study, the writer applies some steps for conducting the experiment, they were: observation, planning, treatment, and post-test. It was conducted in three meetings. To collect the data of this study, the writer using writingtest. Post-test was conducted to both of groups to see the differences between control and experimental groups and also to prove the writer's hypothesis that picture sequences can give an impact to the students' achievement instudents' ability of using conjunction in writing. By using t-test formulation the writer gets value of t-observe 2.178 and the $t$-critical 0.05 is 2.021 It means that $t$-obs value is higher than the $t$-crit. In other word, it can be said that the alternative hypothesis $\left(\mathrm{H}_{1}\right)$ is accepted and null hypothesis $\left(\mathrm{H}_{0}\right)$ is rejected, or it can be said that picture sequences as method that effective and applicable at the eighth grade of MTs. Negeri Model Kota Sorong towards students' ability of using conjunction in writing narrative text.
\end{abstract}

Key Words: Pictures sequences, Conjunction, Writing.

\section{INTRODUCTION}

English is a foreign language subject for students to learn in Indonesia. It has been formulated in the standard of competency and basic competency in the English subject in the Junior High School that covers four aspects of correlated English skills: listening, speaking, reading and writing. Harmer (2007: 265) states that English skills are often divided into two types: Receptive skill is a term used for reading and listening, skills where meaning is extracted from the discourse. Productive skill is the 
term for speaking and writing, skills where students actually have to produce language themselves.

In English language, four skills must be mastered. Writing is one of the four language skills that is very important to learn. But it is not easy. Among the skills, writing is often regarded the most dificult skill for second language to be learned, because it need hard thinking in producing words, sentences, and paragraph. Writing is productive skills in the English language. It means that writing involves communicating a message that can be read and known by the readers. As we known, One scope of English in the Junior High School is that students can produce short functional texts and short essays in the form of procedure, descriptive, narrative and recount texts (Depdiknas 2006). In writing, there are some aspects that should be understood such as grammar, punctuation and spelling, organization, cohesive and coherent devices, and vocabulary. The Students can introduce simple things which are familiar to them. They have to create into short simple texts.

In the teaching learning process of language is often found many problems that faced by students at school. Many students consider that English is difficult. In fact, from the observation when the writer had experience doing experiment, the writer found many problems that is faced by students when they learn English:

The first, less of vocabulary. Vocabulay is one of the basic component which must be mastered by Englishstudents. Some of them said that learning English is not easy, because they are have less vocabulary so it make them dificult in producing words, sentences, or paragraph in English. Usually they also have less confident when they are make paragraph or a short conversation orally, they said that they are afraid and shame for making mistakes oftenly when they use English orally and written. So when the teacher asked them to read a textthey speak very slowly and was not confident to say in pronouncing the words, and also they can not transfer their idea in writting.

The second, they have difficulty make sentencegramatically, short essay, short story, etc. Students still confuse in using tenses. It can be known, when they make a sentence, it could not be done well. They are often confuse to choose a tense that will they use, so they have dificulty in using the appropiate tense at that time. In English we know there are regular and irregular verb, some students confuse to use verb in the tense between V1, V2, V3 and the pronunciation that is not suitable with the written, such as "buy" read "bai" it is not similar with Indonesian words. They also confuse to differentiate about "to be" (Present and Past) they are often make a mistake in using for example, they make a sentence of present tense using to be of past. So it make them can not make a sentence or paragraph at the time.

The Third, less interest to study English, especially in writing. Writing is one of the aspects that is regarded dificult by students because they must find their own ideas to be transferred in writing form, where usually it spent much time to think the ideas that 
will be written in their worksheet. Almost of the students dislike writing, it shown when the writer asked them about which one of the aspects that they like, no one of students who choose writing. They said it isdificult and need hard thinking. Even, students confuse and they did not have any idea to be transfered. They also confuse about usingsome aspect in writing such as grammar, punctuation, spelling, organization, etc. So, they could not make a good chronologically in writing.

The Fourth, management class when the teaching learning process is held. Management class has become one of the problems often faced by every teacher to teach in class. To make quite the students to follow the lesson is not easy, they do anything by theirself to draw attention that disturbing atmosphere of study. Some students were not comfort with this situation because they feel very disturbed by noisy students and can not focus with the lesson.

Based on the discussion and problems above the writer is interrested in finding out students' problem of learning English in students' ability of using conjunction in writing narrative text, where conjunctionis part of speech that used to connect words, phrases, clauses, or sentences,andnarrative text is one of the functional text that learned by students in junior high school. It is kind of text that usually liked by student because the story make the reader amuse, entertain and as their own experience. As we known producing functional short text or writing is one aspect of English that must be mastered by students. It help us in presenting idea, opinion, suggestiuon, comment indirectly, etc. So the learning process is also becomes the crucial part in education especially in writing. But there are still many students of Junior high school difficult to write in English, they confuse to transfer their idea, so it make them difficult to write a text. Usually students did not know about some aspects in writing. Writing to be a complex activity, so the teacher must have an interest strategy to teach English in writing activity. There are many strategies ormethods that may be used to the students' ability in using conjunction of writing narrative text,but must be aware that the methods will be used in teaching and learning must consider many things, including the availability and effectiveness.

To develop students' ability in using conjunction in writing narrative text, the writter tried to offer a technique that using a method. it ispictures sequence. That study entitled, "The Effectiveness Of Picture Sequence TowardsStudent' Ability In Using Conjunction At The Eight Grade Of Mts. Negeri Model Kota Sorong."Picture sequence is a set of pictures which is presented in sequence of event to be used as guidance in writing. By this method is expected effective to stimulate students find the ideas and help students to solve problems in learning English especially for students' ability in using conjunction.

\section{LITERATURE REVIEW}




\section{Some Pertinent Ideas}

\section{Writing}

Writing is one of the four aspects or skills in learning English. It is one way to comunicate with other. Writing is how to produce a written product. It is process of transfering idea coherenly and cohesively into written text. By writing, we can express our thoughts or idea, feeling in writing form. English has became one of subject in Junior High School and writing tobe one of aspect that must be learned and nedeed by students in this school. As we know, where one of scope that student could produce short functional text and short essay in any form (Depdiknas 2006). one of it that relevant with this study is students could produce narrative text.

According to Harmer (2007: 265) writing is one of the active or productive skills, where students actually have to produce language themselves. so that students have to hard thinking find ideas that represent and develop their own idea into writing a text. So it make the students face difficult in writing such as, they are confuseon how to begin to write a paragraph or get stuck on constructing certain genre of the text and do not understand about aspects in writing (grammar, punctuation, spelling, organization, etc). As a statement of Heinkel (2004), he states that according to the earlier study, many difficulties in learning a foreign language will be face by many non-native students. They also identify that these students produce numerous problems and shortfalls in writing activity.

In additions, Leo (2007:1) said that a process of expressing ideas or thoughts in words should be done at our leisure is writing. In this activitystudents are able to express their ideas in written form, but to explore their ideas that will be transferred into a paper the students must have free time and spent much time. The students must be learned and have more experience in writing activity, in orde to get a good written.

According to Boardman (2008:18-25) There are three characteristics in writing a good text or paragraph, namely:

1. Coherence, A paragraph has coherence when the supporting sentences are ordered according to a principle. The sentences are put in order so that the reader can understand your ideas easily. The principles for ordering depend on the types of paragraph you are writing. Coherence means stick together, coherence is basically a matter of having the part of a piece of writing in the right with the clear process.

2. Cohesion, Another characteristic of a good paragraph is Cohesion. When a paragraph has cohesion, all the supporting sentences connect to each other in their support of the topic sentence.

3. Unity, The final characteristic of a well-written paragraph is unity. All the supporting sentences should relate to the topic sentence. Order in text or paragraph is like organization easy, but is smaller in space so it may be simpler to consider 
order as direction. Thus order chronological steps to express the idea the written form

Based on the definitions above, it can be said that writing can be differentiated from other ability as the most difficult one. There are many aspect that influencing writing to be a good one such as; grammatical,vocabularies, punctuation, and spelling knowledge which must be integrated to be a paragraph. It can be concluded that writing is an active or productive skill, physical and mental act, so it more than a medium communication. It is a way of remembering and a way of thinking in producing words, phrase, sentences, and paragraph at the same time and how to produce a written/organizing ideas in which the students is demanded to perform creativity in using the language skills to produce a coherent and cohesive written text based on their ideas to be transferred in a paper or writing form. None of us can write much of interest without first thinking, observing, asking question, experimenting, and reading. So that, for non-active students will be face a numerous problems. So studentsmust have more experiences and learning in writing activity. In order that, they can make a good chronological writing.

\section{METHOD}

The method of this study was quantitative method withexperimental research.Quantitative researchinvolves studies that make use of statistical analyses to obtain their findings. (Marczyk, et al, 2005: 17). The purpose of quantitative methode is to determine the relationship between two variable, they are independen variable and dependent variable(Hopkin, 2008). In this study, the researcher using picture sequence as the independent variable that influence in writing ability in narration text as dependent variable.

This study use true experimental research, according to Christensen (2007: 39), states that experimental study can be defined as a technique, which attempt to find out cause and effect relationship. By this type of study, cause and effect relationship can be isolated. experimental design is to determine cause and effect between independent and dependent variable. A common situation for implementing experimental study involves several classes or schools that can be used to determine the effect of curricular materials or teaching methods. The design of this study is using PosttestOnly Design (Sugiyono, 2015:165). This type of design has two randomly assigned groups: an experimental group and a control group. No one of group is pre-tested before the implementation of the treatment. The treatment is applied to the experimental group and the post-test is carried out on both of groups to assess the effect of the treatment.

\section{Population}


The population of this study is the eight grade of MTs. Negeri Model KotaSorong in the academic year 2016/2017. It was consist of seven classes and each class consists of 28 until 30 students.

\section{The Procedure of the Research}

In this study, the writer applies some steps for conducting the experiment. As follows;

a. Observation

In this study, the writer collecting the problems that related in study Englis especially in writing activity. Then the writer discuss the problems with the English teacher to sellect the problem and knowing the achievement of student' writing ability in narration text. The writer observe both of classes when the English teaching learning is held to take a sample.

b. Planning

The writer prepare lesson plan for both of classes to treatment, post-test.

c. Treatment

The students of experimental class will be given treatment of pictures sequence to write narrative text, meanwhile the students of control class without this methode or using conventional methode or without picture sequences. d. Post-test

Finally, the writer gave post-test for both of experimental and control class and than found out the result achievment of students' writing ability after the treatment.

\section{FINDINGS AND DISCUSSION}

This study is aimed to prove whether the use of pictures sequences is effective in the students' ability of using conjunction inwriting narrative text. Based on the result, it is prove there is a significant difference between students who were taught by using picture sequences and without pictures sequences. It is shown in the null hypothesis was rejected because $t$-observe is higher than the $t$-critical or $H_{1}$ is accepted ( $t_{\text {obs }}>$ $\left.t_{\text {crit }}=2.178>2.021\right)$. It means thatthere is an effetivenes in students' achievement between the students who are taught by using pictures sequences and without picture sequences. So, it can be said that teaching English by using picture sequences is more effective than just giving explanation to the students and it can increase the their achievement and more interest in study English.

Based on the explaination above, can be known that the experimental group is better than control group. It is shown in the high scores of experimental group more than control group and the lower score of control group is more than experimental group. Where, the standart of score value for success treatment is 60-90 and the fail treatment is who get under 60. It means that the students can be more interested by this treatment, motivated, and stimulate students have ideas to use conjunction to 
arrange the words, phrases, sentences in writing form or writeparagraph by looking the pictures sequence, and they can sovel the problems of study English, especially of using conjunction in writing.

\section{CONCLUSION AND SUGGESTION}

Based on the analysis result of this study, it showed that the result of t-observe formula to test the hypothesis of this study. The result showed that there are the benefit and different achievement between students who were taught by using picture sequences and without pictures sequences, where $t$-observe is higher than the $t$ -

critical or $H_{1}\left(t_{o b s}>t_{\text {crit }}=2.178>2.021\right)$. It means that the result of $t$-observe was higher than the result of $t$-critical. So, the null hypothesis $(\mathrm{H} 0)$ is rejected. It means that the answer of the statement of study was proven that there is an effectiveness of Pictures Sequence towards students' ability ofusing conjunctionin writing. This methode also can help some students to face their proplems in studying English, especially in applying conjunction in writing. After the writer carried out the study, she would like to give some suggestion related to the result and discussion. The result of this study showed that theacing using picture sequences is effective to be applied in teaching and learning process

\section{REFERENCES}

Christensen, Larry B. (2007 : 39), Experimental Methodology, 4th ed. Newton, Massachusetts: Allyn and Bacon, Inc.

Departemen Pendidikan Nasional. (2006). Kurikulum Tingkat Satuan Pendidikan (School Based Curriculum) Standar Isi Mata Pelajaran Bahasa Inggris SMP dan MTS. Jakarta: Depdiknas

Harris, $\mathrm{R}$ (2009). Conjunction. [Online]. Available: www.Virtualsalt.com/conjunct.html [23 Maret 2016].

Harmer, J. (2007). How To Teach Writing. New York: Longman

Heinkel, E. (2004). Teaching Academic ESL Writing: Praqctical Techniques in Vocabulary and Grammar. New Jersey: Lawrence Erl Baum Associates, Inc.

John, L. (2000). College Writing Skills with Reading (fifth ed.). New York: McGraw Hill.

Hopkins, D.(2008). A Teacher's Guide to Classroom Research (fourth ed.). Newyork: McGraw Hill-Open University Press. 
INTERACTION: Jurnal Pendidikan Bahasa: Vol. 5, No. 2; October 2018. ISSN: 2406-9558; EISSN : 2406-9566

Leo, S. (2007). English For Academic Purpose :Essay Writing. Jogyakarta : Andi Publisher.

Marczyk, G. (2005). Essentials of Research Desing And Methodology. Canada: John Wiley \& Sons, Inc.

Sugiyono. (2015). Cara Mudah Menyusun Skripsi, Thesis, dan Disertasi. Bandung: Alfabeta. 